\title{
Psychological Well-Being of Contract Employees at PT. Bank X: The Roles of Job Insecurity
} \author{
Syurawasti Muhiddin ${ }^{4}$, \\ ${ }^{1}$ Department of Psychology, Medical Faculty Universitas Hasanuddin, Indonesia \\ ${ }^{2}$ Department of Psychology, Medical Faculty Universitas Hasanuddin, Indonesia \\ ${ }^{3}$ Department of Psychology, Medical Faculty Universitas Hasanuddin, Indonesia \\ ${ }^{4}$ Department of Psychology, Medical Faculty Universitas Hasanuddin, Indonesia \\ *Corresponding author.Email: s.wahyuni@unhas.ac.id
}

Sri Wahyuni ${ }^{1 *}$, Rezky Ariany $\operatorname{Aras}^{2}$, Dayana Melati Mokoginta ${ }^{3}$,

\begin{abstract}
Contract and outsourcing employees are the types of employees widely employed in companies today due to flexibility in terms of length of service agreement and other efficiency reasons. However, a position as a contract employee can create job insecurity. This research aimed to examine the role of job insecurity in the psychological well-being of contract employees at PT. Bank X. This research was also an online survey in which 123 participants filled out two scales, Psychological Well-Being Scales and Job Insecurity Scales. The data were analyzed using simple regression analysis. The results indicate that perceived job insecurity among contract employees at the Bank negatively predicted the psychological well-being, which means that the higher the perceived job insecurity of employees, the lower the psychological well-being of contract employees. This study also implied that job security could be a predictive factor in enhancing the psychological well-being of the contract employees. Therefore, it is essential to ensure that all employees can experience and improve it.
\end{abstract}

Keywords: psychological well-being, job insecurity, contract employees.

\section{INTRODUCTION}

Human resources (HR) is one of the assets that have an essential role in a company. HR carries out various company development activities to achieve the company's goals. Thus, HR should be managed so that they are effective and efficient in completing the visions and missions of the organization [1].

Nowadays, advanced technology and information development have caused labor market changes. The changes indirectly encourage organizations to take various actions to reduce costs and increase efficiency. The actions taken include downsizing, restructuring, mergers, contract employee agreement systems, or outsourcing [2]. The contract employment system is the one that has been widely used by the industry today due to a more flexible working relationship between the company and employees.

However, this contract or outsourcing employees system can be a risk factor causing problems for employees because of the low guarantee of certainty in their work. This system can increase perceived job insecurity. Studies found that the employment contract system is recognized to be detrimental to employees due to a flexible contract system in the specified field, lower wages, minimum limits on social security, and low security for career development [3]. In addition, contract and outsourced employees get different treatment from permanent employees seen from the lower fringe benefits and low opportunity to develop a career in a company [4]. Furthermore, low job security will affect job satisfaction and employees' physical and psychological well-being [5].

\subsection{Psychological Well-Being}

Psychological well-being is a condition of achieving happiness without psychological disorders, which is characterized by the ability of individuals to optimize their psychological functions. This condition is also indicated by the individual's ability to realize and achieve his full potential [6] and describes how an individual's psychological aspects function well and positively $[7,8]$. Moreover, psychological well-being is the highest condition that individuals can achieve, including self-evaluation and acceptance in various 
aspects of life, both positive and negative [9]. In conclusion, it is the highest psychological functioning of individuals.

Psychological well-being in the workplace is the level of psychological feelings and goals that a person feels at work [10]. Moreover, it is described as a condition in which individuals are motivated, engaged at work, have positive energy, enjoy the assignment given, and desire to stay in the organization [11]. Therefore, individuals can realize their positive selfpotential in their work [11].

The dimension of psychological well-being widely used in the literature is proposed by Ryff and Singer [12]. According to them, there are six dimensions of psychological well-being: self-acceptance, positive relation with others, autonomy, environmental mastery, the purpose of life, and personal growth [12]. In terms of a workplace context, Dagenais-Desmarais \& Savoie suggested five dimensions of psychological well-being: interpersonal fit at work, thriving at work, feeling of competency at work, perceived recognition at work, and desire for typical interpretation guidelines [11].

Besides, psychological well-being at the workplace is also influenced by several factors, namely social support [6], work demands [13], imbalance of working conditions [13], low leadership quality [13], role conflicts [14], low job meaning [15], low opportunity to develop [15], low job promotion [15], bullying [13], low awareness of society [13], discrimination [16], demands to hide emotions [17], and job security [18]. Ryff \& Singer added the demographic factors affecting psychological wellbeing at the workplace: age, gender, socio-economic status, work environment, and culture [12].

\subsection{Job Insecurity}

According to several literatures, job insecurity is a condition in which employees experience feelings of threat, worry, and a sense of helplessness because they are faced with uncertain situations about the continuity of their work in the future, including concerns about the possibility of losing their job features which are considered important for an employee [15, 19, 20]. Three characteristics define job insecurity: subjective experiences, involuntary phenomenon, and insecurity about the future [21]

Job insecurity is perceived from two perspectives: a global view and a multidimensional view. The global theory suggests job insecurity as a condition of the threat of job loss or job uncertainty. Meanwhile, in a multidimensional view, job insecurity does not only refer to the uncertainty regarding the continuity of work, but also the continuity of certain jobs, such as opportunities for promotions, declining salary developments, demotion, declining quality of working conditions, concerns about gaps between individuals organization in the future, and various aspects that are considered important by the individual [22].

De Witte suggested two aspects of job insecurity. Firstly, cognitive job insecurity refers to an individual's perception of the possibility of losing his current job. Secondly, affective job insecurity refers to perceived experiences related to job continuity, such as feelings of worry and being threatened with losing the job [23].

\subsection{The Current Study}

This study aimed to examine the role of job insecurity on the psychological well-being of contract employees since the works of literature reveal that psychological well-being at the workplace is affected by job security. This current research targetted the contract employee at PT Bank X. The banking sector is a sector that is heavily influenced by technology where it uses more technology as a substitute for the work performed by employees, for example, the existence of machines such as cash deposits (CDM), automated teller machines (ATM), Mobile Banking as well as there is already a program design in credit matters, for micro, macro, and retail credit [24]. This condition can be perceived as a threat by contract employees. According to a preliminary interview with three contract employees in Bank X, it is revealed that they experienced anxiety due to the lack of certainty about the work he was doing and a feeling of inability to fulfill company rules. They also felt anxious about their position as a contract employee in the company, which means they could be laid off to work in the future. Therefore, we assumed that perceived job insecurity could contribute to contracting employees' psychological well-being.

\section{METHOD}

This study was an online survey that collected data from 123 contract employees at two branches of PT Bank $\mathrm{X}$ in North Sulawesi, using two scales. Psychological Well-being Scales proposed by Ryff had been adapted by Retno and Ratnaningsih [25] and used for this study. It consists of 30 statement items categorized into six dimensions and four answer choices $(1=$ strongly disagree $-4=$ strongly agree) . The examples of the items are 'I will make difficult work as a challenge to improve my performances, and 'the problems I face in the work environment are 
beyond my capabilities. Besides, we used De Witte's Job Insecurity Scale adapted by Patunru [26], consisting of four statement items classified into two aspects with four answers choices. For example, 'I feel insecure about the future of my job' and 'I think that I might lose my job soon. The validity and reliability of the measures were satisfied. Confirmatory Factor Analysis was conducted and revealed the model fit for two measurements. The Cronbach Alpha reliability is also relatively high: 0.896 for Psychological Wellbeing Scales and 0.841 for Job Insecurity Scale. We analyzed the data with linear regression analysis using SPPS 20 for windows.

\section{RESULT}

\subsection{Participants' Profile}

Table 1 describes the summary of the participant's gender and employment status.

Table 1. Gender and Employment Status

\begin{tabular}{ll}
\hline Demographic & $\frac{\text { Total }(n=116)}{n f(\%)}$ \\
\cline { 2 - 3 }
\end{tabular}

\section{Gender}

$\begin{array}{lll}\text { Male } & 50 & 40.7 \\ \text { Female } & 73 & 59.3\end{array}$

\section{Employee Status}

$\begin{array}{lll}\text { Outsourcing } & 57 & 46.3 \\ \text { Bank Contract Employee } & 66 & 53.7\end{array}$

\subsection{Descriptive Statistic}

Table 2 shows the descriptive statistic and the correlations between variables.

Table 2. Statistic Descriptive and Correlation

\begin{tabular}{lllllll}
\hline Variable & Min & Max & M & SD & 1 \\
\hline 1. Job Insecurity & 6 & 16 & 11.5 & 2.3 & \\
\hline $\begin{array}{l}\text { 2.Psychological } \\
\text { well-being }\end{array}$ & 70 & 87 & 78.4 & 3.8 & $0.118^{*}$ \\
\hline
\end{tabular}

The negative correlation described that the higher the job insecurity, the lower the psychological wellbeing of the contract employee.

\subsection{Hypothesis Testing}

The results of regression analysis showed that job insecurity predicted the psychological well-being of contract employee at PT Bank X Makassar, $\mathrm{R}=0.343$, $\mathrm{R} 2=0.118, \mathrm{~F}(1,123)=50.920, \mathrm{p}=<0.001$.

\section{DISCUSSION}

This study aims to examine the contribution of job insecurity to the psychological well-being of contract employees at Bank X. The results show that job insecurity predicts psychological well-being. Therefore, the alternative hypothesis is accepted. However, the predictive power is relatively small by $11,8 \%$.

This study results align with the previous studies, which found that job insecurity may affect psychological well-being. A study conducted by Ramalisa et al. [24] found that job insecurity contributed $73.6 \%$ to psychological well-being. Research by Dhiba [27] revealed that job insecurity predicted psychological well-being by $31.6 \%$. Moreover, a study conducted by Rizky \& Sadida [28] found that job insecurity influences psychological well-being with a correlation coefficient of -0.603 .

Furthermore, the degree of job insecurity prediction is not as strong as the prediction in the previous study. This also reflects that there are possibilities of other factors influencing the psychological well-being of employees. For example, social support, inter-role conflict, job demands, and low leadership quality [13]. Demographic factors may also be associated with psychological well-being, such as age, gender, work environment, and culture, including collectivistic and individualistic cultures [12].

Warr [29] suggests that the vitamin models theory is related to job insecurity, which impacts psychological well-being. This theory has a main component, namely uncontrollability, that explains the lack of control that individuals have or the feeling of helplessness against threats, which is a core of the phenomenon of job insecurity. If this condition is experienced in the long term, it will have a significant impact on the psychological well-being of employees. 
A sense of security in life is one of the factors that individuals must meet to reach the stage of selfactualization. However, the emergence of job insecurity in employees will result in psychological problems and unfulfillment of the drive for security needs in individuals. Maslow suggests that selfactualization will be achieved if all the drive needs have been met in the individual, such as physiological needs, security needs, needs for love and belonging, and esteem needs [30]. The insecurity felt by employees due to job uncertainty will affect the individual's self-actualization stage, which can further impact psychological well-being [31].

Individual interpretation of the position in the reality of the work environment can affect the psychological well-being of employees. Core evaluations, in this case, have a positive role in shaping the psychological condition of employees. A positive interpretation of experience will lead to employees' satisfaction as the foundation for optimizing psychological well-being functions [32]. Meanwhile, negative experiences (e.g., job insecurity) make employees feel threatened and uncomfortable with their work, resulting in unhappiness and low life satisfaction [33].

Job insecurity generally occurs in contract employees with temporary work durations. Employment agreements with a period and not permanent can lead to a higher possibility of feeling worried about losing their job in contract employees. Employees also do not have more control to do what they want in their work [34]. The position of employees who are only contract employees and employees who have an equivalent high school education level will find it more challenging to obtain certainty in the extension of the work contract with the company. It can cause problems if there is a threat of losing their job. If experienced in the long term, these problems can cause job insecurity and cause psychological disturbances to employees [23].

Low psychological well-being is described by conditions in which individuals do not optimally carry out their psychological functions. Individuals are also unable to evaluate themselves positively and do not act independently, and are easily influenced by the environment [6]. Individuals with impaired psychological well-being at work are associated with poorer mental health outcomes, for example, anxiety, sleep disturbances, and depression. Thus, high job insecurity will affect a person's mental health at work and in life outside the workplace.
This study has several limitations that can be overcome in subsequent similar studies. This study did not involve controls in submitting the hypothesis in terms of the analysis. Subsequent research can consider several demographic variables as controls to increase confidence regarding the contribution of independent variables. Regarding the procedure, the data collection was conducted online, so the researcher cannot find out directly and confirm whether the questionnaires have been filled in with the actual conditions of the employees. Furthermore, related to the number of samples, the coverage of contract employees can be expanded, not only in two bank branches. The contract employee may also come from the different contexts of the organization outside the bank. Considering the proportion of sex and age is also important for future research. All of these conditions can increase confidence in the generalization process of the findings. In general, further research can be designed to examine which aspects of work-life balance psychological well-being are affected by job insecurity more. Other factors can be involved as independent, mediating, and moderating variables to serve a more comprehensive model of psychological well-being factors in the workplace.

\section{CONCLUSION}

Job insecurity plays a role in predicting the low psychological well-being of contract employees at PT. $X$ Bank. The higher the job insecurity, the lower the psychological well-being of contract employees. Conversely, the lower the job insecurity, the higher the level of psychological well-being of contract employees. However, the predictive power is relatively small, allowing other factors to predict psychological well-being as well. This research also implies that job insecurity can harm workers' mental health. Thus, efforts are needed to reduce the experience in the company.

\section{REFERENCES}

[1] Sastrohadiwiryo, B. S. Manajemen Tenaga Kerja Indonesia: pendekatan administrative dan operasional. Bumi Aksara: Jakarta.E.M. 2005.

[2] Hellgren J, Sverke M. Does job insecurity lead to impaired well-being or vice versa? Estimation of cross-lagged effects using latent variable modelling. Journal of Organizational Behavior: The International Journal of Industrial, Occupational and Organizational Psychology and Behavior. 2003 Mar;24(2):215-36. 
[3] Sutedi A. Good corporate governance. Sinar Grafika; 2011.

[4] Andina E. Ketidakpuasan buruh alih daya. Info Singkat Pusat Pengkajian, Pengolahan Data dan Informasi Sekretariat Jenderal Dewan Perwakilan Rakyat Indonesia. 2013;5(9).

[5] Heaney CA, Israel BA, House JS. Chronic job insecurity among automobile workers: Effects on job satisfaction and health. Social science \& medicine. 1994 May 1;38(10):1431-7.

[6] Ryff CD. Happiness is everything, or is it? Explorations on the meaning of psychological well-being. Journal of personality and social psychology. 1989 Dec;57(6):1069.

[7] Aspinwall, L.G. A psychology of Human Strengths: Fundamental questions and future directions for positive psychology. Washington, DC: American Psychological Association. 2002.

[8] Tanujaya W. Hubungan Kepuasan Kerja Dengan Kesejahteraan Psikologis (Psychological Well Being) Pada Karyawan Cleaner (Studi Pada Karyawan Cleaner Yang Menerima Gaji Tidak Sesuai Standar UMP di PT. Sinergi Integra Services, Jakarta)". Jurnal Psikologi. 2014;12(2):67-79.

[9] Lakoy FS. Psychological well-being perempuan bekerja dengan status menikah dan belum menikah. Jurnal psikologi. 2009 Dec;7(2):71-80.

[10] Robertson IT, Cooper CL, Johnson S. Wellbeing: Productivity and happiness at work. Basingstoke: Palgrave macmillan; 2011 Apr 27.

[11] Dagenais-Desmarais, V. D., \& Savoie, A. What is psychological well-being, really? A grassroots approach from the organizational sciences. Journal of Happiness Studies. 2012;(13), 659684. doi: 10.1007/s10902-011 -9285-3.

[12] Ryff CD, Singer B. Psychological well-being: Meaning, measurement, and implications for psychotherapy research. Psychotherapy and psychosomatics. 1996;65(1):14-23.

[13] Schütte S, Chastang JF, Malard L, ParentThirion A, Vermeylen G, Niedhammer I. Psychosocial working conditions and psychological well-being among employees in 34 European countries. International archives of occupational and environmental health. 2014 Nov;87(8):897-907.

[14] Spector, P. E. Industrial and Organizational Psychology Research and Practice (second edition). New York : Jhon Wily \& Sons, Inc. 2000 .
[15] Ashford SJ, Lee C, Bobko P. Content, cause, and consequences of job insecurity: A theory-based measure and substantive test. Academy of Management journal. 1989 Dec 1;32(4):803-29.

[16] Liliweri A. Komunikasi antar personal. Prenada Media; 2017.

[17] Hochschild., Luis L., Eddleston., Kimberly., Veiga., \& John. "Moderators of the Relationship Between Work-Family Conflict and Career Satisfaction". Academy of Management Journal. 45(2). 399- 409. 2011.

[18] Sverke M. Job insecurity and union membership: European unions in the wake of flexible production. Peter Lang; 2004.

[19] Esther R, GREENGLASS I, RONALD J. IMPACT OF RESTRUCTURING JOB INSECURITY AND SATISFACTION IN HOSPITAL NURSES. 2002.

[20] Greenhalgh L, Rosenblatt Z. Job insecurity: Toward conceptual clarity. Academy of Management review. 1984 Jul 1;9(3):438-48.

[21] Vander Elst T, De Witte H, De Cuyper N. The Job Insecurity Scale: A psychometric evaluation across five European countries. European Journal of Work and Organizational Psychology. 2014 May 4;23(3):364-80.

[22] Mauno S, Kinnunen U. Perceived job insecurity among dual-earner couples: Do its antecedents vary according to gender, economic sector and the measure used?. Journal of Occupational and Organizational Psychology. 2002 Sep;75(3):295-314.

[23] De Witte H. Job insecurity: Review of the international literature on definitions, prevalence, antecedents and consequences. SA Journal of Industrial Psychology. 2005 Jan 1;31(4):1-6.

[24] Lisa R, Marpaung W, Manurung Y. Kesejahteraan Psikologis Ditinjau Dari Ketidakamanan Kerja Pada Karyawan Kontrak PT. Bank Rakyat Indonesia, Tbk Cabang Medan Thamrin. Psikostudia: Jurnal Psikologi. 2020 Mar 31;9(1):31-7.

[25] Simanullang RT, Ratnaningsih IZ. Hubungan Antara Kesejahteraan Psikologis Dengan Keterikatan Kerja Pada Perawat Instalasi Rawat Inap Di Rumah Sakit X Kota Semarang (Doctoral dissertation, Undip). 2018.

[26] Patunru, A, R. Kontribusi Job Insecurity terhadap Turnover Intentioin Karyawan Di Perusahaan Transportasi X Kota Makassar. 
Universitas Hassanuddin: Program Studi Psikologi. 2018.

[27] Dhiba, H. Hubungan job insecurity dan Dukungan Keluarga dengan Kesejahteraan Psikologis pada Karyawan Kontrak. Program Studi Psikologi, Universitas Islam Negeri Sunan Kalijaha Yogyakarta. 2018.

[28] Rizky TR, Sadida N. Hubungan antara Job Insecurity dan Employee Well Being pada Karyawan yang Bekerja di Perusahaan yang Menerapkan PHK di DKI Jakarta. Jurnal EMPATI. 2019 Jan 2;8(1):329-35.

[29] Warr P. Work, unemployment, and mental health. Oxford University Press; 1987.

[30] Snyder CR, Lopez SJ. The future of positive psychology. Handbook of positive psychology. 2002:751-67

[31] Nopiando B. Hubungan antara job insecurity dengan kesejahteraan psikologis pada karyawan outsourcing. Journal of Social and Industrial Psychology. 2012;1(2).

[32] Nuzulia S. Peran Core Evaluations Terhadap Kepuasan Kerja dan Psychological Well-being. Intuisi: Jurnal Psikologi Ilmiah. 2009 Jul 30;1(2):125-31.

[33] Nolan, J. The intensification of everyday life. In B.J. Burchell, D. Ladipo, and F. Wilkinson (eds.). Job Insecurity and Work Intensification. Journal of Gender, Work \& Organization. London: Routledge. 2002

[34] Gallie D, Felstead A, Green F, Inanc H. The hidden face of job insecurity. Work, employment and society. 2017 Feb;31(1):36-53. 